\title{
Understanding the Barriers for School Garden Success: Expert Consensus to Guide Extension Programming ${ }^{1}$
}

\author{
Susan Webb, John Diaz, and Catherine Campbell ${ }^{2}$
}

\section{Introduction}

Research has found that youth involvement in school gardens leads to numerous benefits, such as improved academic student achievement, development, health, environmental attitudes, and knowledge of food systems (Berenguer, 2007; Dirks \& Orvis, 2005; Graham, Feenstra, Evans, \& Zidenberg-Cherr, 2004; Morris, Briggs, \& Zidenberg-Cherr, 2000; Rahm, 2002; Skelly \& Zajicek, 1998; Waliczek \& Zajicek, 1999; Williams \& Dixon, 2013). For these reasons, school gardens are increasingly popular nationally and internationally as learning spaces. However, research also documents the barriers that teachers and support organizations must overcome for garden sustainability, including a lack of tangible and intangible resources, changes and demands within the education system, and concerns for student health and safety in the garden (Barker, Slingsby, \& Tilling, 2002; Comishin, Dyment, Potter \& Russell, 2010; Clay, 1999; Dillon \& Dickie, 2011; Dillon, Morris, O’Donnell, Reid, Rickinson, \& Scott, 2005; Dyment, 2005; Edward-Jones, Waite \& Passy, 2016; Graham \& Zidenberg-Cherr, 2005; Hazzard, Moreno, Beall, \& Zidenberg-Cherr, 2011; Kelly \& Cutting, 2011; Lugg, 2004; Ogilvie, 2012; Ozer, 2007; Rickinson, Dillon, Teamey, Morris, Choi, Sanders \& Benefield, 2004; Rickinson, Hunt, Rogers, Dillon, 2012; Waite, 2011).

\section{Significance/Need}

Often, school garden leaders look to outside organizations for assistance in addressing these barriers. Extension faculty and staff are commonly contacted by teachers, administrators, and school support staff to provide education, resources, and even volunteers. Tailoring responses to each individual garden site is necessary, but can also be timeconsuming for agents. To develop a streamlined process for faculty and staff to incorporate the self-identified needs of school gardeners into new and/or existing programming, the authors conducted a statewide study of stakeholder school garden barriers in Florida.

\section{The Delphi Process}

The Delphi method is an iterative research process designed to collect data from numerous stakeholders to elicit consensus around a topic or question. This process was used with a statewide expert panel of participants from state agencies, non-profits, institutions of higher learning, and various school systems across the state. Participants $(\mathrm{n}=74)$ responded to three successive surveys designed to assess participant consensus on barriers, challenges, and obstacles for starting and sustaining school gardens. In round 1, the survey prompted participants to list all the barriers, challenges, and obstacles that came to mind. These data were then analyzed by the researchers and grouped into categories of barriers. In round 2, participants were

1. This document is WC315, one of a series of the Agricultural Education and Communication Department, UF/IFAS Extension. Original publication date August 2018. Visit the EDIS website at http://edis.ifas.ufl.edu.

2. Susan Webb, Extension agent I; John Diaz, assistant professor and Extension specialist; and Catherine Campbell, postdoctoral research associate; UF/ IFAS Extension, Department of Agricultural Education and Communication, Gainesville, FL 32611. 
asked to rate their agreement using a Likert scale on how important it is to address each category. Two-thirds of participants had to strongly agree or agree that the category was important to reach group consensus. Only those items that had a two-thirds majority were included in round 3. The same process was used to gather data for round 3. The results of round 3 are presented below and represent the final categories that two-thirds or more of participants agreed were important to address to ensure the successful development and sustainability of a school garden program.

\section{Findings and Implementation}

Results from round 3 identified a lack of time among teachers to manage the garden program (93.2\%), lack of continuity of maintenance activities ( $84.7 \%)$, challenges associated with volunteer management and retention (81.4\%), lack of continuity in leadership (78\%), issues of implementing an innovative program into an already existing system built upon traditional classroom instruction (76.3\%), lack of initial sustained participation among parents, students, volunteers and teachers (74.6\%), and the complexity of school systems (69.5\%) as the most important barriers, challenges, or obstacles to address to ensure program development and sustainability. While some of these challenges, such as the complexity of school systems, are outside the scope of the influence of Extension faculty staff, Extension can support programming that targets local challenges. A list of recommendations for programming to address each barrier, challenge, or obstacle is listed below in Table 1. These recommendations have proven successful in various contexts and provide a means to overcoming these pervasive impediments to school garden success.

Extension faculty and staff can use these findings to tailor programming to some of the most common barriers to program success. The following are examples of activities that faculty and staff can incorporate into new and/or existing programs for school gardens to address common barriers, such as structuring learning events to include multiple people from one garden, encourage skills like community engagement and volunteer management, and the use of timely, targeted communications. These activity recommendations are grounded in the authors' experience in working with school gardens. Furthermore, the authors tailored the recommendations to fit the structure of Extension programming.

\section{Summary}

While school gardens continue to provide significant beneficial impacts for participants, they continue to face pervasive barriers that may compromise their long-term utilization and success. Extension is positioned to provide meaningful support to help these gardens overcome the barriers they face, but it is impossible for all of barriers to be addressed. The barriers outlined in this paper provide Extension with the key barriers that need to be overcome and allows organizational synergy and support if these remain the focus of Extension programs.

\section{References}

Barker, S., Slingsby, D., \& Tillin, S. (2002). Teaching biology outside the classroom. Is it heading for extinction? Retrieved from http://www.field-studies-council.org/ media/268869/2002_biology_fieldwork._is_it_heading_for_extinction.pdf

Berenguer, J. (2007). The effect of empathy in proenvironmental attitudes and behaviors. Environment and Behavior, 39(2), 269-283.

Clay, G. (1999). Outdoor and adventurous activities: an OfSTED survey. British Journal of Physical Education, 30(2), 13-15.

Comishin, K., Dyment, J. E., Potter, T. G., \& Russell, C. L. (2004). The development and implementation of outdoorbased secondary school integrated programs. Applied Environmental Education and Communication, 3(1), 47-53.

Dillon, J., \& Dickie, I. (2012). Learning in the Natural Environment: Review of Social and Economic Benefits and Barriers. Retrieved from http://publications.naturalengland. org.uk/publication/1321181

Dillon, J., Morris, M., O’Donnel, L., Reid, A., Rickison, M., Scott, W. (2005). Engaging and Learning with the Outdoors - The Final Report of the Outdoor Classroom in a Rural Context Action Research Project. Retrieved from http://educationoutdoor.com/wp-content/uploads/2015/10/ Engaging-and-Learning-with-the-outdoors.pdf

Dirks, A. E., \& Orvis, K. (2005). An evaluation of the junior master gardener program in third grade classrooms. HortTechnology, 15(3), 443-447.

Dyment, J. (2005). Green school grounds as sites for outdoor learning: Barriers and opportunities. International Research in Geographical and Environmental Education, 14(1), 28-45. doi:10.1080/09500790508668328

Edward-Jones, A., Waite, S., \& Passy, R. (2016). Falling into LINE: School strategies for overcoming challenges 
associated with learning in natural environments (LINE). Education 3(13), 1-15. doi:10.1080/03004279.2016.1176066

Graham, H., Feenstra, G., Evans, A. M., \& ZidenbergCherr, S. (2004). Davis school program supports life-long healthy eating habits in children. California Agriculture, 58, 200-205. doi:10.3733/ca.v058n04p200

Graham, H \& Zidenberg-Cherr, S. (2005). California teachers perceive school gardens as an effective nutritional tool to promote healthful eating habits. Journal of the American Dietetic Association, 105(11), 1797-1800.

Hazzard, E.L., Moreno, E., Beall, D. L., \& Zidenberg-Cherr, S. (2011). Best practices models for implementing, sustaining, and using instructional school gardens in California. Journal of Nutrition Education and Behavior, 43(5), 409-413.

Kelly, O., \& Cutting, R. (2011). Understanding places and society through history and geography outside the classroom. In Children Learning Outside the Classroom: From Birth to Eleven, edited by S.Waite, 106-119. London: Sage.

Lugg, A. (2004). Outdoor adventure in Australian outdoor education: Is it a case of roast for Christmas dinner? Australian Journal of Outdoor Education, 8(1), 4-11.

Morris, J., Briggs, M., \& Zidenberg-Cherr, S. (2000). School-based gardens can teach kids healthier eating habits. California Agriculture, 54(5), 40-46.

Ogilvie, K. C. (2013). Roots and wings: A history of outdoor education and outdoor learning in the UK. Lyme Regis:

Russell House Publishing.

Ozer, E. (2007). The effects of school gardens on students and schools: conceptualization and considerations for maximizing healthy development. Health Education \& Behavior, 34(6), 846-863. doi:10.1177/1090198106289002

Rahm, J. (2002). Emergent learning opportunities in an inner-city youth gardening program. Journal of Research in Science Teaching, 39(2), 164-184.

Rickinson, M, Dillon, J., Teamey, K., Morris, M., Choi, M.Y., Sanders, D., \& Benefield, P. (2004). A review of research on outdoor learning. National Foundation for Educational Research and King's College London. Retrieved from https:// www.field-studies-council.org/media/268859/2004_a_review_of_research_on_outdoor_learning.pdf
Rickinson, M., A. Hunt, J. Rogers, and J. Dillon. (2012). School leader and teacher insights into learning outside the classroom in natural environments. Natural England Commissioned Reports, Number 97.

Skelly, S. M., \& Zajicek, J. M. (1998). The effect of an interdisciplinary garden program on the environmental attitudes of elementary school students. HortTechnology, 8(4), 579-583.

Waite, S. (2011). Teaching and Learning Outside the Classroom: Personal Values, Alternative Pedagogies and Standards. Education 3-13: International Journal of Primary, Elementary and Early Years Education, 39(1): 65-82. doi:10.1080/03004270903206141.

Waliczek, T. M., \& Zajicek, J. M. (1999). School gardening: Improving environmental attitudes of children through hands-on learning. Journal of Environmental Horticulture, 17(4), 180-184.

Williams, D. R., \& Dixon, P. S. (2013). Impact of gardenbased learning on academic outcomes in schools: Synthesis of research between 1990 and 2010. Review of Educational Research, 83(2), 211-235. 
Table 1. Addressing challenges through Extension programming.

\begin{tabular}{|c|c|}
\hline Barrier, Challenge, or Obstacle & Extension Activity to Address Challenge \\
\hline $\begin{array}{l}\text { Lack of time among teachers to manage garden } \\
\text { program }\end{array}$ & $\begin{array}{l}\text { - Tailor programming to encourage garden teams to work together to manage the } \\
\text { garden. }\end{array}$ \\
\hline Lack of continuity of maintenance activities & $\begin{array}{l}\text { - Provide garden teams with education and assistance in creating maintenance plans and } \\
\text { schedules. } \\
\text { - Communicate timely, targeted tasks during the growing season (for example, } \\
\text { communication on what to plant when, preparing for frost protection, and prepping } \\
\text { the garden for the winter and summer breaks). }\end{array}$ \\
\hline $\begin{array}{l}\text { Challenges associated with volunteer } \\
\text { management and retention }\end{array}$ & - Offer teacher trainings that target volunteer recruitment and management strategies. \\
\hline $\begin{array}{l}\text { Issues of implementing an innovative program into } \\
\text { an already existing system built upon traditional } \\
\text { classroom instruction }\end{array}$ & $\begin{array}{l}\text { - Support teachers in identifying and utilizing garden-based learning curriculum that } \\
\text { meets standards. }\end{array}$ \\
\hline $\begin{array}{l}\text { Lack of initial sustained participation among } \\
\text { parents, students, volunteers, and teachers }\end{array}$ & $\begin{array}{l}\text { - Incorporate community engagement best practices into trainings and workshops. } \\
\text { - Train Master Gardeners and Master Food and Nutrition volunteers to work specifically in } \\
\text { school gardens. }\end{array}$ \\
\hline Complexity of school systems & $\begin{array}{l}\text { - Outreach to school district administrators to highlight the benefits, successes, and also } \\
\text { barriers to school gardens with an emphasis on how school districts can support efforts. }\end{array}$ \\
\hline
\end{tabular}

